\title{
THE HEMODYNAMIC “TARGET”: A VISUAL TOOL OF GOAL-DIRECTED THERAPY FOR SEPTIC PATIENTS
}

\author{
Fabrice Vallée, Olivier Fourcade, Philippe Marty, Pascale Sanchez, Kamran
} Samii, Michèle Genestal

Vallée F, Fourcade O, Marty F, Sanchez P, Samii K, Genestal M. The hemodynamic "target": a visual tool of goal-directed therapy for septic patients. Clinics. 2007;62(4):447-54.

OBJECTIVE: To improve understanding of the hemodynamic status of patients with sepsis by nursing teams through the attainment of hemodynamic parameters using a pentaxial "target" diagram as a clinical tool. Parameters include cardiac index (CI), arterial oxygen saturation $\left(\mathrm{SaO}_{2}\right)$, mean arterial pressure (MAP), arterial blood lactate, and central venous oxygen saturation $\left(\mathrm{ScvO}_{2}\right)$.

METHODS: Design: Prospective descriptive study. Setting: The intensive care unit of a university hospital. Patients: During a 6month period, 38 intubated septic shock patients were included in the study. Survivors and nonsurvivors were compared. Interventions: MAP, CI, $\mathrm{SaO}_{2}, \mathrm{ScvO}_{2}$ and lactate were measured at 0, 6, 12, 24, 36, and $48 \mathrm{~h}$. Measurements were recorded on the target diagram along with the norepinephrine infusion rate and the hemoglobin $(\mathrm{Hb})$ level. The number of lactate and $\mathrm{ScvO}_{2}$ measurements achieved during the target period were compared to a 6-month retrospective control period just before starting the protocol. We assessed the nurse knowledge status prior to the introduction of target diagram. We then performed a post-test after implementing the new recording technique.

MEASUREMENTS AND RESULTS: The nursing team expressed a positive attitude toward the target concept. The mean number of lactate and $\mathrm{ScvO}_{2}$ measurements performed for each patient during the control period was significantly lower than during the target period, and those values were rarely used as goal values before the introduction of the target diagram. At 24 hours, $46 \%$ of the survivors had achieved all the goal parameter values of the target diagram, compared to only $10 \%$ of nonsurvivors $(P=.01)$. CONCLUSION: The target diagram is a visual multiparametric tool involving all the medical and nursing team that helps achieve goal-directed therapy for septic patients. The number of goal values reached at each time point during the first 48 hours was closely linked to mortality.

KEYWORDS: Guidelines translating. Clinical practice. Septic patients. End Point. Target tool

\section{INTRODUCTION}

The early diagnosis and treatment of septic patients is currently an important public health issue because of the high incidence and mortality rate of severe sepsis. ${ }^{1}$ A worldwide campaign has been carried out since 2004 with the aim of conveying the right therapeutic attitudes in order to improve the prognosis of septic patients. ${ }^{2}$ Now, physicians are facing a new challenge, ie, how to translate science to

Anesthesia and Intensive Care Unit Department, Purpan University Hospital, Toulouse, France

Received for publication on March 26, 2007

Accepted for publication on May 12, 2007

Email : vallee.f@chu-toulouse.fr practical application. ${ }^{3,4}$ In order to help the physician, authors try to define tools to synthesize evidence for use in bedside practice, helping to reduce variations and uncertainty in practice. ${ }^{5}$ Hollenberg et $\mathrm{al}^{6}$ argue that for hemodynamic management, it is fundamental that clinicians define specific goals and end points, titrate therapies to those end points, and continually evaluate the results of their interventions by monitoring multiple variables of global and regional perfusion.

To achieve this end, like Shoemaker in the 1980 s, ${ }^{7}$ we have designed a target diagram to visualize the hemodynamic goals of septic patients. These parameters reflect oxygen delivery (cardiac index - CI, arterial oxygen saturation - $\mathrm{SaO}_{2}$, 
and hemoglobin - $\mathrm{Hb}$ ); tissue perfusion (mean arterial pressure - MAP); oxygen tissue extraction (central venous oxygen saturation - $\mathrm{ScvO}_{2}$ ); and cellular ischemia (blood lactate concentration) (Figure 1). The central grey area on the target diagram encircles the goal values of these parameters, ie, CI: 31/ $/ \mathrm{min} / \mathrm{m}^{2}, \mathrm{SaO}_{2}$ : 95\%, MAP: $65 \mathrm{~mm} \mathrm{Hg}$, lactate: 2 $\mathrm{mmol} / \mathrm{L}$, and $\mathrm{ScvO}_{2}: 70 \%$. The scales for each parameter were selected arbitrarily by the authors with reference to international recommendations on hemodynamic goals. ${ }^{6}$ The more the value of a parameter worsens, the more its place on the target diagram moves away from the center. The target diagram is charted for a patient by joining together the values of the 5 parameters. Thus, if the therapeutic goals are achieved, the patient's test values lie within the central circle.

The main aim of this preliminary descriptive study was to evaluate over a 6-month period in our institution the effects of the use of this target diagram for developing understanding by the nursing team of the septic patient's hemodynamic status.

The second aim was to evaluate whether the systematic use of the target diagram can improve goal completion. Finally, we analyze the relationship between the number of goals reached at each time point and the patient's outcome.

\section{MATERIALS AND METHODS}

\section{Patients}

After approval by our institution's ethics committee, during a 6-month period (from July to December 2005), all patients with septic shock, ${ }^{2}$ mechanically ventilated; under sedation; and having a central venous line, an arterial line, and cardiac output monitoring with a $\mathrm{PICCO}^{\mathrm{TM}}$ monitor were included in the study and placed in an adult intensive care unit of 16 beds in a university hospital.

\section{Methods}

Mean arterial pressure and $\mathrm{ScvO}_{2}$ were continuously measured using an arterial catheter and pulse oxymetry; $\mathrm{Hb}$ was measured every 12 hours; and blood lactate concentration $(\mathrm{mmol} / \mathrm{L})$ was obtained from an arterial sample. Central venous oxygen saturation was obtained from a sample taken from the central venous line in the superior vena cava (position verified by X-ray, with the tip of the catheter superimposed on the fourth right intercostal space, just above the azygos cross). Cardiac index (CI) $\left(\mathrm{L} / \mathrm{min} / \mathrm{m}^{2}\right)$ was obtained using the $\mathrm{PICCO}^{\mathrm{TM}}$ monitor by taking the average of 3 transpulmonary thermodilution results.

There were no therapeutic instructions in the protocol.
All treatment decisions were at the discretion of the treating physician. MAP, CI, $\mathrm{SaO}_{2}, \mathrm{ScvO}_{2}$, and lactate measurements were systematically made at $0,6,12,24,36$, and 48 hours (H0, H6, H12, H24, H36, and H48), in addition to those prescribed by the physician in charge of the patient. These were then recorded by the nursing team on a target diagram, a self-adhesive sticker placed on patient's treatment chart (Figures 1 and 2).

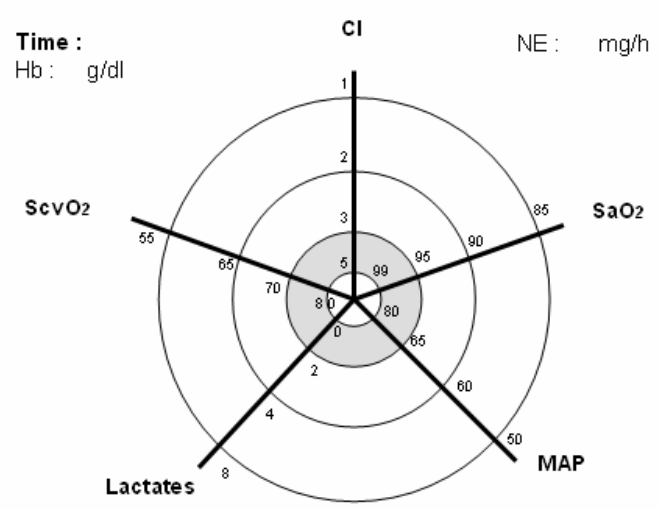

Figure 1 - The hemodynamic target diagram

Parameters of the target diagram and their scales: MAP (mean arterial pressure): normal range, $65-80 \mathrm{~mm} \mathrm{Hg}$; CI (cardiac index): normal value $>3$ $\mathrm{L} / \mathrm{min} / \mathrm{m}^{2} ; \mathrm{SaO}_{2}$ (arterial oxygen saturation): normal range, 95\%-99\%; Lactate, obtained from an arterial sample: normal value $<2$ mmol/L; $\mathbf{S c v O}_{2}$ (central venous oxygen saturation): normal range $>70 \%$; Hb (hemoglobin): $\mathrm{g} / \mathrm{dL} ; \mathbf{N E}$ (norepinephrine): $\mathrm{mg} / \mathrm{h}$.

The 5 parameters of the target diagram schematically represent oxygen delivery (CI, $\mathrm{SaO}_{2}$ ), tissue perfusion (MAP), cellular ischemia (lactates), and oxygen extraction $\left(\mathrm{Scv} \mathrm{O}_{2}\right)$. The central gray circle indicates the goal values of these parameters. The more the value of a parameter worsens, the more its place on the target diagram moves away from the center. The target area is drawn by joining together the values of the 5 parameters. The more the surface area represented by the 5 points is large and moves away from the gray circle, the more the patient is hemodynamically unstable. One can then visually judge adequacy between oxygen delivery (right side of the target diagram) and oxygen consumption (left side of the target diagram).

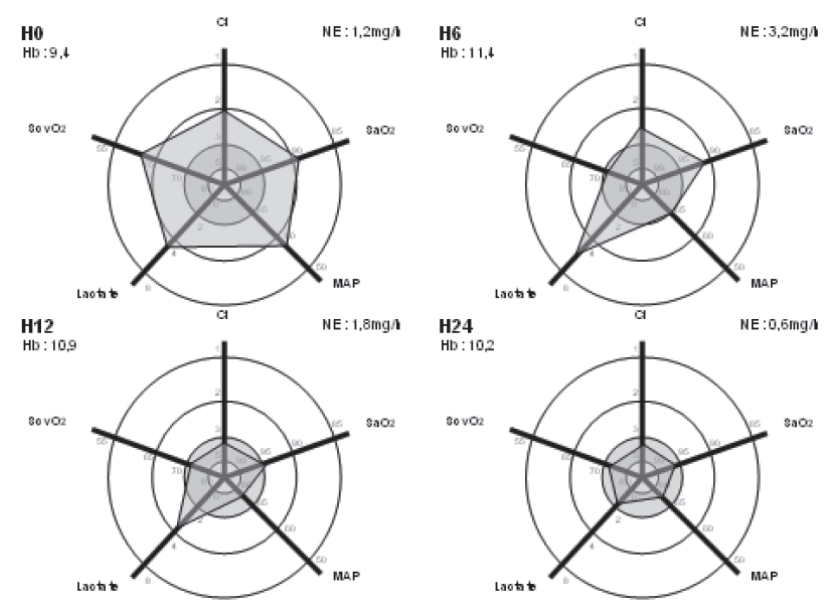

Figure 2 - Evolution of the target area between $\mathrm{H} 0$ and $\mathrm{H} 24$ for a patient in septic shock due to pneumonia: improvement of target parameters and reduction in the norepinephrine administration starting from $\mathrm{H} 12$. 
All patients included were compared to a retrospective control group including all the septic shock patients during the 6 months before starting protocol (January to June 2005). Control and target groups were compared for age, gender, Simplified Acute Physiology Score (SAPS II), diagnosis, mortality within 28 days, and number of lactate and $\mathrm{ScvO}_{2}$ measurements.

In the target group, patients were split into survivors and nonsurvivors according to the mortality at 28 days. These two groups were compared regarding age, gender, SAPS II score, diagnosis, and target parameters at H0, H6, $\mathrm{H} 12, \mathrm{H} 24, \mathrm{H} 36$, and $\mathrm{H} 48$, as well as their average value over the 48 hours of the study. The proportion of survivors and nonsurvivors reaching the goal values of parameters at each time point were also compared. We assessed the nurses' knowledge status prior to the introduction of target diagram, implemented the new recording technique, and then performed a post-test.

Questions before introduction of the target diagram were as follows: 1- Describe the significance of an elevated lactate concentration in patients with hypotension. 2- Describe the significance of a low $\mathrm{ScvO}_{2 \mathrm{~h}}$ in patients with hypotension. 3 Which parameters reflect a stable hemodynamic status?

Questions after the introduction of the target diagram were as follows: 1- Describe the significance of an elevated lactate concentration in patients with hypotension. 2- Describe the significance of a low $\mathrm{ScvO}_{2}$ in patients with hypotension. 3- Which parameters reflect a stable hemodynamic status? 4- Do you think it is interesting to use the target diagram? 5- Does the target diagram help you to better understand the hemodynamic profile of your patient? 6- Did the use of the target diagram increase your work load?

\section{Statistical analysis}

Parameters were compared in the control and target periods, and in the survivors and the nonsurvivors of the target period using ANOVA or a nonparametric MannWhitney $U$ test when equality of variance was not met. Data were expressed as mean \pm standard deviation (SD). A $P$ value $\mathrm{d} \bullet .05$ was considered statistically significant.

\section{RESULTS}

\section{Follow-up and evaluation of the use of the target diagram by the nursing team}

We received 39 questionnaires from the 42 nurses in the unit before the target period and 41 after the target period.

Responses before versus after the introduction of the target diagram were, respectively, are summarized below:

- did not know the significance of an elevated lactate con- centration in patients with hypotension, $49 \%$ versus $26 \%(P=.04)$;

- did not know the significance of a low $\mathrm{ScvO}_{2}$ in patients with hypotension, $79 \%$ versus $30 \%(P<.01)$.

- did not know that macrocirculatory and microcirculatory parameters (lactates and $\mathrm{ScvO}_{2}$ ) are basic measurements for hemodynamic assessment, $59 \%$ versus $15 \%$ $(P=.01)$.

Thirty-one (79\%) believed the target diagram had helped them to better understand the hemodynamic profile of their patients and that the target diagram will help in the earlier detection and thus the prevention of hemodynamic instability. Most $(82 \%)$ replied that it gave them a more global view of the hemodynamic status of their patients. Thirty-three (85\%) said the target diagram did not increase their workload. Sixty-seven percent of the nurses were spontaneously using the target diagram and its parameters during nursing team hand-over meetings.

\section{Characteristics of the patients during the target period and the retrospective control period (Table 1)}

Table 1 - Characteristics of septic shock patients during the 2 periods. Demographic data, diagnosis, and number of blood lactate and $\mathrm{ScvO}_{2}$ measurements.

\begin{tabular}{lccc}
\hline Patients & Controlperiod & Target period & $P$ \\
\hline $\mathrm{N}$ & 42 & 38 & \\
Age (mean $\pm \mathrm{SD})^{*}$ & $58.4 \pm 17.1$ & $63.7 \pm 13.7$ & .13 \\
SAPS II (mean $\pm \mathrm{SD})$ & $63.8 \pm 19.7$ & $59.9 \pm 19.8$ & .37 \\
Mortality D28 (n (\%)) & $25(59)$ & $20(52)$ & .1 \\
\hline Diagnosis & & & \\
\hline Pneumonia (n (\%)) & $17(40)$ & $13(34)$ & .56 \\
Peritonitis (n (\%)) & $6(14)$ & $11(28)$ & .08 \\
Urinary infection (n (\%)) & $2(5)$ & $1(3)$ & .62 \\
Necrotizing fascitis (n (\%)) & $3(7)$ & $4(11)$ & .29 \\
Hematological disease n (n (\%)) & $7(17)$ & $6(16)$ & .92 \\
Other (n (\%)) & $7(17)$ & $3(8)$ & .24 \\
Lactate measurements/patient (n (range)) & $2.9(1-6)$ & $5.5(2-6)$ & .001 \\
ScvO measurements/patient (n (range)) & $0.2(0-2)$ & $5.5(2-6)$ & $<.001$ \\
\hline
\end{tabular}

In 2005,80 patients were admitted to our unit for septic shock: 42 during the control period and 38 during the target period. Control and target periods were comparable for the number of patients, the SAPS II score, and the diagnosis. There was no significant difference in mortality between the two groups. The mortality for these septic patients was $56 \%$. The patients of the target period had significantly more lactate and $\mathrm{ScvO}_{2}$ measurements than the patients of the control period (average number of measurements, respectively, 2.9 vs 5.5 for lactate and 0.2 vs 5.5 for $\mathrm{ScvO}_{2}$ ). 


\section{Survivor and nonsurvivor characteristics during the target period (Table 2)}

Table 2 - Demographic data, diagnosis, mortality rate, and norepinephrine and dobutamine receiving during the first 2 days, comparing survivors and nonsurvivors of the target group.

\begin{tabular}{lccc}
\hline & Survivors & Nonsurvivors & $P$ \\
\hline $\mathrm{n}(\%)$ & $18(48)$ & $20(52)$ & \\
Age (mean \pm SD) & $58.5 \pm 12.7$ & $67.4 \pm 13.5$ & .05 \\
SASP II score (mean \pm SD) & $47.6 \pm 12.4$ & $68.8 \pm 19.6$ & $<.001$ \\
Diagnosis: & $5(31)$ & $8(36)$ & .74 \\
Pneumonia (n (\%)) & $5(31)$ & $6(27)$ & .76 \\
Peritonitis (n (\%)) & $0(0)$ & $1(5)$ & .38 \\
Urinary infection (n (\%)) & $2(12)$ & $2(9)$ & .73 \\
Necrotizing fascitis (n (\%)) & $3(19)$ & $3(14)$ & .66 \\
Hematological disease (n (\%)) & $1(7)$ & $2(9)$ & .74 \\
Other (n (\%)) & $/$ & $6(27)$ & \\
Mortality D3 (n (\%)) & $/$ & $16(73)$ & \\
Mortality D8 (n (\%)) & $/$ & $22(100)$ & \\
Mortality D28 (n (\%)) & $16(100)$ & $22(100)$ & .98 \\
Norepinephrine (n (\%)) & $3(18)$ & $4(18)$ & .96 \\
Dobutamine (n (\%)) & & & \\
\hline
\end{tabular}

During the protocol, 38 patients were included; 18 patients survived. Nonsurvivors were significantly older and had significantly higher SAPS II scores than survivors. Four patients died within the first 3 days, and 16 within the first week. At the time of inclusion, all patients received norepinephrine, and 7 (18\%) of them also received dobutamine within the first 2 days. There was no difference in the number of patients who received dobutamine in the survivor and nonsurvivor groups.

\section{Comparison of target parameters between survivors and nonsurvivors (Table 3 and 4)}

Regarding numbers of measurements, 211 target measurements were collected, with an average of 5.5 measurements per patient (a maximum of 6); 96 measurements were obtained in survivors and 115 in nonsurvivors. At H0, there was no significant difference between survivors and nonsurvivors for all target parameters: MAP, $\mathrm{CI}, \mathrm{SaO}_{2}$, lactate, $\mathrm{ScvO}_{2}$, hemoglobin, and norepinephrine infusion rate. During the following 2 days, however, survivors had significantly higher MAP and $\mathrm{SaO}_{2}$, as well as lower blood lactate concentrations and norepinephrine infusion rates.

At $\mathrm{H} 24,46 \%$ of the survivors had reached all the goals of the target vs only $10 \%$ of the nonsurvivors. This difference remained significant for the next 24 hours (Table 4).

\section{DISCUSSION}

The introduction of the target diagram was well ac- cepted by the paramedical staff. The whole of the nursing team pointed out the advantages of the target diagram for the understanding of hemodynamic instability during septic shock. The relevance of linking the observation of usual parameters (MAP, heart rate, urinary output, $\mathrm{SaO}_{2}$ ) with those parameters reflecting peripheral tissue perfusion (lactates, $\mathrm{ScvO}_{2}$ ) has been understood by them. According to $98 \%$ of the nursing team, the target diagram therefore seemed to be a relevant and appropriate tool. They believe that the target diagram will help them in the earlier detection and thus in the prevention of hemodynamic failure. They appreciated the visual aspect of the tool, its ability to be copied, and its simplicity (Figure 2).

The analysis of our practice during the 6 months before the introduction of the target diagram confirmed that, in spite of physician knowledge of "early goal-directed therapy" and the Surviving Sepsis Campaign, $\mathrm{ScvO}_{2}$ and lactate measurements were not routinely performed in our unit (Table 2). The usefulness of both parameters during the early phase of septic shock has been proved, ${ }^{8-11}$ and their measurement forms part of the guidelines in the Surviving Sepsis Campaign. ${ }^{2}$ The use of the target diagram facilitated the systematic measurement of these two parameters in our unit; they are now considered essential for the septic patient and are included in the radar chart together with the other usual parameters.

When all of the parameters of the target diagram are considered together, our results show that the proportion of patients "inside the target" (all the goals reached) was significantly higher in survivors than in nonsurvivors from H24 to H48 (H24: $46 \%$ vs $10 \%, P=.01$; H36: $53 \%$ vs. $17 \%, P=.02$; H48: $66 \%$ vs. $24 \%, P=.01$ ) These differences are less remarkable if one examines the results on a goal-by-goal basis (Table 4). This reinforces the advantage of a tool giving a global view of parameters reflecting macrocirculatory and microcirculatory function; it facilitates the better appreciation of the patient's hemodynamic status (Figure 2). Hollenberg et $\mathrm{al}^{6}$ argue that clinicians treating septic patients should define specific goals and end points, titrate therapies to those end points, and evaluate the results of their interventions. With the target diagram, we can use the radar chart to follow the performance of the goal-directed therapy of septic patients. Our results show that the number of goals reached during the first 2 days are linked to the patient's outcome (Table 4).

We chose the target parameters with reference to international recommendations on hemodynamic goals ${ }^{6}$ but also to reflect both oxygen delivery (right side of the target diagram) and oxygen tissue extraction and cellular ischemia (left side of the target diagram) (Figure 1). Accordingly, it seems to be an important point to have a visual assessment regard- 
Table 3 - Target parameters in survivors and nonsurvivors: cardiac index (CI), arterial oxygen saturation $\left(\mathrm{SaO}_{2}\right)$, mean arterial blood pressure (MAP), blood lactate concentration, oxygen central venous saturation $\left(\mathrm{ScvO}_{2}\right)$, norepinephrine regimen, and hemoglobin concentration in survivors and nonsurvivors of the target group.

\begin{tabular}{|c|c|c|c|c|c|c|c|}
\hline & HO & H6 & $\begin{array}{c}\mathrm{H} 12 \\
\text { CI - L/min/m² }\end{array}$ & H24 & H36 & H48 & H0-H48 \\
\hline Survivors(range) & $\begin{array}{l}3.6 \pm 0.6 \\
(2.8-5.2)\end{array}$ & $\begin{array}{l}3.9 \pm 0.6 \\
(2.8-5.6)\end{array}$ & $\begin{array}{c}4 \pm 0.6 \\
(2.9-5.4)\end{array}$ & $\begin{array}{l}4.2 \pm 0.5 \\
(3.2-5)\end{array}$ & $\begin{array}{c}4.3 \pm 0.55 \\
(2.9-5)\end{array}$ & $\begin{array}{l}4.3 \pm 0.3 \\
(3.7-5.2)\end{array}$ & $\begin{array}{l}4.1 \pm 0.4 \\
\quad(2.8-5.6)\end{array}$ \\
\hline Non-Survivors(range) & $\begin{array}{l}3.5 \pm 1.1 \\
(2.2-5.4)\end{array}$ & $\begin{array}{l}3.6 \pm 1.2 \\
(2.1-5.4)\end{array}$ & $\begin{array}{c}3.6 \pm 1.1 \\
(2-5.8)\end{array}$ & $\begin{array}{l}3.6 \pm 1.1 \\
(2.2-5.6)\end{array}$ & $\begin{array}{l}3.7 \pm 1.1 \\
(2.3-5.8)\end{array}$ & $\begin{array}{l}3.8 \pm 0.9 \\
(2.2-5.7)\end{array}$ & $\begin{array}{c}3.5 \pm 1.1 \\
(2-5.8)\end{array}$ \\
\hline$P$ & .78 & .2 & .2 & .02 & .05 & .06 & .06 \\
\hline \multicolumn{8}{|c|}{$\mathrm{SaO}_{2}-\%$} \\
\hline Survivors(range) & $\begin{array}{c}96 \pm 2 \\
(90-99)\end{array}$ & $\begin{array}{c}96 \pm 2 \\
(88-100)\end{array}$ & $\begin{array}{c}96 \pm 3 \\
(90-100)\end{array}$ & $\begin{array}{c}96 \pm 2 \\
(93-100)\end{array}$ & $\begin{array}{c}97 \pm 1 \\
(94-99)\end{array}$ & $\begin{array}{c}97 \pm 2 \\
(93-99)\end{array}$ & $\begin{array}{c}96 \pm 2 \\
(88-100)\end{array}$ \\
\hline Nonsurvivors(range) & $\begin{array}{c}94 \pm 3 \\
(88-98)\end{array}$ & $\begin{array}{c}94 \pm 3 \\
(86-99)\end{array}$ & $\begin{array}{c}94 \pm 3 \\
(86-98)\end{array}$ & $\begin{array}{c}94 \pm 4 \\
(86-99)\end{array}$ & $\begin{array}{c}94 \pm 4 \\
(85-99)\end{array}$ & $\begin{array}{l}94 \pm 4 \\
(85-98)\end{array}$ & $\begin{array}{c}93 \pm 4 \\
(85-99)\end{array}$ \\
\hline$P$ & .09 & .06 & .04 & .05 & .09 & .02 & .01 \\
\hline \multicolumn{8}{|c|}{ MAP - mm Hg } \\
\hline Survivors(range) & $\begin{array}{c}65 \pm 4 \\
(58-75)\end{array}$ & $\begin{array}{c}68 \pm 7 \\
(60-77)\end{array}$ & $\begin{array}{c}71 \pm 4 \\
(65-78)\end{array}$ & $\begin{array}{c}72 \pm 4 \\
(62-82)\end{array}$ & $\begin{array}{c}73 \pm 4 \\
(63-79)\end{array}$ & $\begin{array}{l}76 \pm 3 \\
(66-79)\end{array}$ & $\begin{array}{c}72 \pm 3 \\
(58-82)\end{array}$ \\
\hline Non-Survivors(range) & $\begin{array}{c}63 \pm 6 \\
(55-75)\end{array}$ & $\begin{array}{l}68 \pm 3 \\
(54-76)\end{array}$ & $\begin{array}{c}67 \pm 6 \\
(52-78)\end{array}$ & $\begin{array}{c}67 \pm 8 \\
(54-79)\end{array}$ & $\begin{array}{l}69 \pm 8 \\
(56-85)\end{array}$ & $\begin{array}{l}70 * \pm 6 \\
(63-82)\end{array}$ & $\begin{array}{c}65 \pm 6 \\
(52-85)\end{array}$ \\
\hline$P$ & .06 & .2 & .07 & .08 & .08 & .03 & .003 \\
\hline \multicolumn{8}{|c|}{ Lactate concentration $\mathrm{mmol} / \mathrm{L}$} \\
\hline Survivors(range) & $\begin{array}{l}3.6 \pm 2.1 \\
(1.7-7.1)\end{array}$ & $\begin{array}{l}4.1 \pm 2.1 \\
(1.3-7.3)\end{array}$ & $\begin{array}{l}3.2 \pm 2.1 \\
(0.8-7.0)\end{array}$ & $\begin{array}{l}1.9 \pm 1.1 \\
(0.7-4.3)\end{array}$ & $\begin{array}{l}1.8 \pm 0.9 \\
(0.6-4.2)\end{array}$ & $\begin{array}{l}1.7 \pm 0.7 \\
(0.6-3.3)\end{array}$ & $\begin{array}{l}2.7 \pm 1.3 \\
(0.6-7.3)\end{array}$ \\
\hline Nonsurvivors(range) & $\begin{array}{c}4.3 \pm 3.3 \\
(1.1-14.2)\end{array}$ & $\begin{array}{c}4.7 \pm 4.3 \\
(1.5-16.8)\end{array}$ & $\begin{array}{c}4.6 \pm 3.6 \\
(1.3-12.1)\end{array}$ & $\begin{array}{c}6.2 \pm 4.7 \\
(1.1-16.4)\end{array}$ & $\begin{array}{l}5.2 \pm 4.5 \\
(0.9-6.1)\end{array}$ & $\begin{array}{c}4.7 \pm 4.9 \\
(0.9-17.5)\end{array}$ & $\begin{array}{l}5.2 \pm 3.5 \\
(0.9-17.5)\end{array}$ \\
\hline$P$ & .48 & .63 & $\begin{array}{c}.18 \\
\mathrm{ScvO}_{2}-\%\end{array}$ & .001 & .007 & .03 & .02 \\
\hline Survivors(range) & $\begin{array}{c}71 \pm 8 \\
(55-86)\end{array}$ & $\begin{array}{l}75 \pm 6 \\
(66-89)\end{array}$ & $\begin{array}{c}77 \pm 6 \\
(69-88)\end{array}$ & $\begin{array}{c}76 \pm 5 \\
(67-85)\end{array}$ & $\begin{array}{c}77 \pm 6 \\
(68-90)\end{array}$ & $\begin{array}{c}78 \pm 5 \\
(67-85)\end{array}$ & $\begin{array}{c}76 \pm 4 \\
(55-90)\end{array}$ \\
\hline Nonsurvivors(range) & $\begin{array}{l}71 \pm 10 \\
(53-90)\end{array}$ & $\begin{array}{c}73 \pm 8 \\
(57-88)\end{array}$ & $\begin{array}{c}73 \pm 9 \\
(60-90)\end{array}$ & $\begin{array}{l}75 \pm 10 \\
(55-95)\end{array}$ & $\begin{array}{l}76 \pm 7 \\
(65.92)\end{array}$ & $\begin{array}{c}77 \pm 7 \\
(68-88)\end{array}$ & $\begin{array}{l}72 \pm 10 \\
(55-95)\end{array}$ \\
\hline$P$ & .82 & .28 & .24 & .88 & .67 & .9 & .16 \\
\hline \multicolumn{8}{|c|}{ Norepinephrine $\mathrm{mcg} / \mathrm{kg} / \mathrm{min}$} \\
\hline Survivors(range) & $\begin{array}{l}0.61 \pm 0.2 \\
(0.09-1.2)\end{array}$ & $\begin{array}{l}0.57 \pm 0.2 \\
(0.13-1.1)\end{array}$ & $\begin{array}{c}0.49 \pm 0.2 \\
(0.04-1)\end{array}$ & $\begin{array}{c}0.39 \pm 0.22 \\
(0-0.93)\end{array}$ & $\begin{array}{l}0.28 \pm 0.2 \\
(0.13-0.8)\end{array}$ & $\begin{array}{c}0.2 \pm 0.3 \\
(0.04-1.2)\end{array}$ & $\begin{array}{c}0.42 \pm 0.2 \\
(0-1.2)\end{array}$ \\
\hline Nonsurvivors(range) & $\begin{array}{c}0.78 \pm 0.37 \\
(0.31-1.4)\end{array}$ & $\begin{array}{c}0.84 \pm 0.36 \\
(0.35-1.7)\end{array}$ & $\begin{array}{l}0.75 \pm 0.6 \\
(0.2-2.23)\end{array}$ & $\begin{array}{c}0.81 \pm 0.7 \\
(0-2.51)\end{array}$ & $\begin{array}{c}0.49 \pm 0.6 \\
(0-2.11)\end{array}$ & $\begin{array}{c}0.41 \pm 0.5 \\
(0-1.89)\end{array}$ & $\begin{array}{c}0.68 \pm 0.3 \\
(0-2.51)\end{array}$ \\
\hline$P$ & .24 & .02 & .1 & .03 & .2 & .3 & .02 \\
\hline \multicolumn{8}{|c|}{ Hemoglobin - g/dL } \\
\hline Survivors(range) & $\begin{array}{l}10.5 \pm 2.1 \\
(6.7-13.5)\end{array}$ & $\begin{array}{c}11.4 \pm 1.2 \\
(8.9-13)\end{array}$ & $\begin{array}{c}11.2 \pm 0.8 \\
(9.5-13)\end{array}$ & $\begin{array}{l}11.2 \pm 0.5 \\
(10.5-12)\end{array}$ & $\begin{array}{c}11.2 \pm 0.8 \\
(9.8-12)\end{array}$ & $\begin{array}{c}11 \pm 0.7 \\
(9.7-12.4)\end{array}$ & $\begin{array}{l}11.1 \pm 0.7 \\
(6.7-13.5)\end{array}$ \\
\hline Nonsurvivors(range) & $\begin{array}{c}11 \pm 2.3 \\
(6.7-15.6)\end{array}$ & $\begin{array}{c}11.3 \pm 1.7 \\
(8.8-14)\end{array}$ & $\begin{array}{l}11.7 \pm 1.1 \\
(9.8-13.7)\end{array}$ & $\begin{array}{l}11.1 \pm 0.7 \\
(9.5-12.4)\end{array}$ & $\begin{array}{c}11.6 \pm 1.2 \\
(9.5-3.5)\end{array}$ & $\begin{array}{c}10.8 \pm 1.1 \\
(9.3-13)\end{array}$ & $\begin{array}{c}11.2 \pm 1 \\
(6.7-15.6)\end{array}$ \\
\hline$P$ & .5 & .8 & .7 & .45 & .3 & .4 & .8 \\
\hline
\end{tabular}

ing oxygen delivery and consumption, as recommended by Squara. ${ }^{12}$ For this reason, we included $\mathrm{CI}, \mathrm{SaO}_{2}, \mathrm{Hb}, \mathrm{MAP}$, $\mathrm{ScvO}_{2}$, and lactates, even if it is an imperfect image of the $\mathrm{DO}_{2} / \mathrm{VO}_{2}$ ratio. The evolution of these parameters is variable over the first 2 days, and so should be further evaluated (Table 3). In any case, the concept of a target diagram as a monitoring tool is not fixed. The parameters included, their goal levels, scales, and the frequency with which they are assayed can evolve according to their utility, relevance, practicality, and the developing evidence base. The introduction of the target diagram was simple, and its use was readily accepted by the nursing staff. This acceptance insured the continuous use of this tool after the study period. The target concept has revealed a way to involve all the medical and paramedical staff in the care of septic patient. We are conscious that it is not the only way, but in our ICU, it helped us to follow the 
Table 4 - Proportion of patients reaching target goal value at each time point:

\begin{tabular}{lcccccc}
\hline survivors vs nonsurvivors. & $\begin{array}{c}\text { H0 } \\
\text { patients with all target goals reached }\end{array}$ & H6 & H12 & H24 & H36 & H48 \\
\hline Survivors (\%) & 12 & 34 & 34 & 46 & 53 & 66 \\
Nonsurvivors (\%) & 4 & 12 & 9 & 10 & 17 & 24 \\
$P$ & 0.06 & 0.13 & 0.08 & 0.01 & 0.02 & 0.01 \\
\hline
\end{tabular}

patients with at least $\mathbf{4}$ target goals reached

\begin{tabular}{lcccccc}
\hline Survivors (\%) & 41 & 60 & 87 & 86 & 86 & 93 \\
Nonsurvivors (\%) & 4 & 36 & 55 & 55 & 53 & 65 \\
$P$ & 0.05 & 0.2 & 0.03 & 0.03 & 0.04 & 0.05
\end{tabular}

patients with at least 3 target goals reached

\begin{tabular}{lcccccc}
\hline Survivors (\%) & 74 & 100 & 100 & 100 & 100 & 100 \\
Nonsurvivors (\%) & 43 & 86 & 80 & 80 & 82 & 83 \\
$P$ & 0.07 & 0.08 & 0.07 & 0.07 & 0.1 & 0.15 \\
\hline
\end{tabular}

\begin{tabular}{lcccccc}
\hline \multicolumn{7}{c}{ patients with at least 2 target goals reached } \\
\hline Survivors (\%) & 100 & 100 & 100 & 100 & 100 & 100 \\
Nonsurvivors (\%) & 81 & 86 & 88 & 80 & 82 & 83 \\
$P$ & 0.08 & 0.08 & 0.2 & 0.07 & 0.1 & 0.15 \\
\hline
\end{tabular}

\begin{tabular}{lcccccc}
\hline \multicolumn{7}{c}{ patients with at least 1 target goal reached } \\
\hline Survivors (\%) & 100 & 100 & 100 & 100 & 100 & 100 \\
Nonsurvivors (\%) & 96 & 91 & 88 & 90 & 88 & 84 \\
$P$ & 0.4 & 0.14 & 0.21 & 0.21 & 0.17 & 0.08 \\
\hline
\end{tabular}

performance of goal-directed therapy. We think that the visual concept of the tool, which can evolve, is an argument for involving all the team.
However, we understand the limitations of our study, as follows: a) being a prospective descriptive study with no standardized therapy procedures and no therapeutic instructions, b) using a retrospective control group, c) including only a few patients, and d) being only a monocentric study, with the usefulness of the target diagram being assessed only by 1 nursing department staff.

\section{CONCLUSION}

This observational study is preliminary, since it only introduces a visual diagram of monitoring, without studying the potential impact on patient outcome. However, it has enabled us to detect deficiencies in the monitoring of septic patients in our unit, ie, that $\mathrm{ScvO}_{2}$ and lactate were not regularly monitored even in the early phase. The introduction of the target diagram has facilitated the inclusion of these two variables on the list of basic monitoring parameters for septic patients. Actually we are considering another study with a therapeutic algorithm to assess impact of the target diagram on septic patients' outcomes.

The last phase of the Surviving Sepsis Campaign involves translating the guidelines for septic patients in clinical practice to create a global best practice for sepsis management. ${ }^{5,13}$ For hemodynamic support, the creation of a multiparametric monitoring tool such as the target diagram has revealed a way to educate and involve the nursing team in this aim.

\section{RESUMO}

Vallée F, Fourcade O, Marty F, Sanchez P, Samii K, Genestal M. Alvo Hemodinâmico: uma ferramenta visual de terapia "goal-directed" para pacientes sépticos. Clinics. 2007;62(4):447-54.

OBJETIVO: Melhorar a compreensão do "status" hemodinâmico de pacientes em sepse pelas equipes de enfermagem através da obtenção de parâmetros hemodinâmicos usando um diagrama-alvo pentaxial como ferra- menta clínica. Os parâmetros usados foram índice cardíaco, saturação arterial de oxigênio, pressão arterial media, lactato sangüíneo arterial e saturação venosa central de oxigênio.

MÉTODOS: Estudo descritivo prospectivo, realizado na Unidade de Terapia Intensiva de um Hospital Universitário. Pacientes: Durante um período de 6 meses, 38 pacientes intubados em choque séptico foram incluídos no estudo. Foram comparados sobreviventes vs. não sobreviven- 
tes. Intervenções: Os cinco parâmetros referidos foram medidos nas horas $0,6,12,24,36$ e 48. As medidas foram registradas no diagrama alvo, juntamente com a velocidade de infusão de norepinefrina e nível de hemoglobina. O número de medidas de lactato e saturação venosa central de oxigênio realizado durante o período de estudo foi comparado com um período retrospectivo de 6 meses imediatamente precedendo a introdução do protocolo. Avaliamos o nível de conhecimento das equipes de enfermagem antes da introdução do diagrama-alvo. Após a realização do protocolo realizamos uma nova avaliação.

MEDIDAS E RESULTADOS: A equipe de enfermagem exprimiu uma atitude positiva em relação ao conceito de diagrama alvo. O número de medidas de lactato e saturação venosa central de oxigênio foi significativamente me- nor durante o período controle anterior ao protocolo. E os valores medidos raramente foram empregados como valores meta antes da introdução do diagrama-alvo. Na medida de 24 horas, $46 \%$ dos sobreviventes haviam atingido todas as metas do diagrama-alvo, contra apenas $10 \%$ dos não sobreviventes $(\mathrm{P}=0,01)$.

CONCLUSÃO. O diagrama-alvo é uma ferramenta visual multiparamétrica envolvendo, as equipes médicas e de enfermagem, que auxilia a obtenção de uma estratégia terapêutica para pacientes sépticos. O número de valores meta atingidos a cada momento durante as primeiras 48 horas relaciona-se à mortalidade

UNITERMOS: Diretrizes. Prática clínica. Pacientes sépticos. Metas. Ferramenta alvo.

\section{REFERENCES}

1. Friedman G, Silva E, Vincent JL. Has the mortality of septic shock changed with time. Crit Care Med. 1998;26:2078-86.

2. Dellinger RP, Carlet JM, Masur H, Gerlach H, Calandra T, Cohen J, et al. Surviving Sepsis Campaign guidelines for management of severe sepsis and septic shock. Crit Care Med. 2004;32:858-73.

3. Rivers EP. Early goal-directed therapy in severe sepsis and septic shock: converting science to reality. Chest. 2006:129:217-8.
4. Trzeciak S, Dellinger RP, Abate N, Cowan R, Stauss M, Parillo JE. Translating research to clinical practice: a 1-year experience with implementing early goal-directed therapy for septic shock in the emergency department. Chest. 2006:129:225-32.

5. Cinel I, Dellinger RP. Guidelines for severe infections: are they useful? Curr Opin Crit Care. 2006;12:483-8. 
6. Hollenberg SM, Klein LW, Parillo JE, Scherer M, Dums D, Tamburo P, et al. Practice parameters for hemodynamic support of sepsis in adult patients: 2004 update. Crit Care Med. 2004;32:1928-48.

7. Shoemaker WC. Circulatory mechanisms of shock and their mediators. Crit Care Med. 1987;15:787-94.

8. Rivers E, Nguyen B, Havstad S, Ressler J, Muzzin A, Knoblich B, et al. Early goal-directed therapy in the treatment of severe sepsis and septic shock. N Engl J Med. 2001;345:1368-77.

9. Nguyen HB, Rivers EP, Knoblich BP, Jacobsen G, Muzzin A, Ressler JA. Early lactate clearance is associated with improved outcome in severe sepsis and septic shock. Crit Care Med. 2004;32:1637-42.
10. Bernardin G, Pradier C, Tiger F, Deloffre P, Mattei M. Blood pressure and arterial lactate level are early indicators of short-term survival in human septic shock. Intensive Care Med. 1996;22:17-25.

11. Vincent JL, Dufaye P, Berre J, Leeman M, Degaute JP, Kahn RJ. Serial lactate determinations during circulatory shock. Crit Care Med. 1983;11:449-51.

12. Squara P. Matching total body oxygen consumption and delivery: a crucial objective? Intensive Care Med. 2004;30:2170-9.

13. Levy MM, Pronovost PJ, Dellinger RP, Townsend S, Resar RK, Clemmer TP, et al. Sepsis change bundles: converting guidelines into meaningful change in behavior and clinical outcome. Crit Care Med. 2004;32 (11 Suppl):S595-7. 